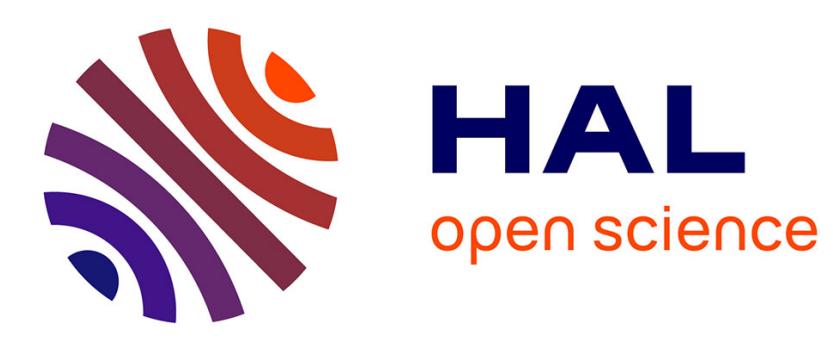

\title{
Investigations of a Ferrimagnetic Spinel-Garnet Composite System
}

\author{
N. Kumar, P. Venugopal Reddy, P. Kishan
}

\section{To cite this version:}

N. Kumar, P. Venugopal Reddy, P. Kishan. Investigations of a Ferrimagnetic Spinel-Garnet Composite System. Journal de Physique IV Proceedings, 1997, 07 (C1), pp.C1-551-C1-552. 10.1051/jp4:19971227 . jpa-00254900

\section{HAL Id: jpa-00254900 https://hal.science/jpa-00254900}

Submitted on 1 Jan 1997

HAL is a multi-disciplinary open access archive for the deposit and dissemination of scientific research documents, whether they are published or not. The documents may come from teaching and research institutions in France or abroad, or from public or private research centers.
L'archive ouverte pluridisciplinaire HAL, est destinée au dépôt et à la diffusion de documents scientifiques de niveau recherche, publiés ou non, émanant des établissements d'enseignement et de recherche français ou étrangers, des laboratoires publics ou privés. 


\title{
Investigations of a Ferrimagnetic Spinel-Garnet Composite System
}

\author{
N. Kumar, P. Venugopal Reddy* and P. Kishan* \\ Solid State Physics Laboratory, Lucknow Road, Delhi - 110054, India \\ * Department of Physics, Osmania University, Hyderabad - 500007, India
}

\begin{abstract}
A composite system comprising of two ferrimagnetic oxide compounds, a spinel and a garnet, has been investigated. A series of materials with varying proportion of the contents of magnesium manganese ferrite and yttrium iron garnet, both of quality suitable for microwave applications, have been prepared and studied in relation to the parent materials. Results obtained from examination of samples by XRD and EPMA coupled with electrical and magnetic measurements have been used to understand the observed behaviour.
\end{abstract}

\section{INTRODUCTION}

Ferrimagnetic oxide materials having the spinel and garnet structures are extensively employed in a variety of components operating in microwave frequency ranges. Magnesium-manganese ferrites and yttrium-iron garnets are among the families of such materials which are being used for almost four decades. Substitutions of different metal ions in the basic ferrite/garnet chemical formula unit are exploited to tailor and control the properties of the material. Composites of magnetic oxides with other dielectric materials have been of interest to researchers working in this field[1,2]. System of the type described in this paper has not been found in literature. The aim of the present work is to prepare the spinel-garnet composites containing the individual compounds in different proportions and study their properties in relation to the parent materials to find out whether their salient features could be exploited in the composites.

\section{MATERIALS AND METHODS}

Ferrite of chemical composition $\mathrm{Mg}_{0.9} \mathrm{Cu}_{0.1} \mathrm{Mn}_{0.1} \mathrm{Fe}_{1.8} \mathrm{O}_{4}(\mathrm{MF})$ and garnet of $\mathrm{Y}_{3} \mathrm{Mn}_{0.03} \mathrm{Fe}_{4.92} \mathrm{O}_{12}$ (YIG) were prepared separately by standard ceramic methods. AR grade oxide/carbonate of $\mathrm{Mg}, \mathrm{Mn}$ and $\mathrm{Cu}$ were used while $\mathrm{Fe}_{2} \mathrm{O}_{3}$ of purity $3 \mathrm{~N}^{+}$and $\mathrm{Y}_{2} \mathrm{O}_{3}$ of $4 \mathrm{~N}+$ were employed. The mixed raw materials were repeatedly ball-milled and calcined. The calcining temperatures used were 1000 and $1100^{\circ} \mathrm{C}$ respectively for MF and YIG powders. From XRD patterns of the calcined powders almost complete formation of the desired spinel phase was observed while the garnet phase formation was not so. Samples in the form of a disc and a toroid from both the powders were pressed and sintered at 1275 and $1450{ }^{\circ} \mathrm{C}$ for 4 hours. Dense samples so obtained were tested by XRD and for other properties. The measurements indicated the formation of single phase material with desired properties, (samples $\mathrm{C} 1$ and $\mathrm{C} 13$ listed in Table I). The composites of MF and YIG were prepared by thoroughly mixing the two sets of calcined powders in ball mills in different weight ratio (marked $\mathrm{C} 2$ to $\mathrm{C} 12$, Table I). Samples were fired in the range 1275 to $1450^{\circ} \mathrm{C}$.

All samples were analysed by XRD. C1 and C13 samples had better than $96 \%$ and $99 \%$ of their respective theoretical densities. Other samples were also estimated to have similar densities. Measurements of properties like saturation magnetisation ( $4 \pi \mathrm{Ms})$, Curie temperature $(\mathrm{Tc})$, dc resistivity $\left(\rho_{\mathrm{dc}}\right)$ initial permeability $\left(\mu_{\mathrm{i}}\right)$, $3 \mathrm{~dB}$ resonance linewidth $(\Delta \mathrm{H})$ at $\mathrm{X}$ band and hysteresis loop parameters were carried out using standard test methods. Some of the samples were also examined by CAMECA Electron Probe Micro Analyser (EPMA) for observing microstructural distribution of the phases present.

\section{RESULTS AND DISCUSSION}

From the XRD analysis of the samples it is observed that as the content of YIG in MF is increased the diffraction lines corresponding to YIG start appearing in the patterns of samples from C5 onwards. The samples C10 to C12 show only the lines of the garnet phase. However, C5 to C9 contain some extra lines which were identified as belonging to perovskite yttrium-orthoferrite $\left(\mathrm{YFeO}_{3}\right)$ phase: These lines are quite strong in the samples $\mathrm{C} 6$ to $\mathrm{C} 8$. It is reported[3] that the free energy 
of formation of $\mathrm{YFeO}_{3}$ is at least one order of magnitude lower than that of garnet and $\mathrm{YFeO}_{3}$ is found as an intermediate product in this process of preparation of YIG [4]. It is observed here that when the MF content is substantial both orthoferrite and garnet phases get formed in the samples. In YIG rich samples ( $\mathrm{C} 10$ to $\mathrm{C} 12)$ perovskite phase is not observed, may be due to its small content. At the sintering temperatures employed here complete conversion of $\mathrm{YFeO}_{3}$ to YIG phase was expected.

Table I. Properties of the samples

\begin{tabular}{|c|c|c|c|c|c|c|c|c|c|c|c|c|c|}
\hline $\begin{array}{l}\text { wt. tatio } \\
\text { (YIG:MF) }\end{array}$ & $\begin{array}{c}\mathrm{Cl} \\
0: 100\end{array}$ & $\begin{array}{c}\text { C2 } \\
1: 99\end{array}$ & $\begin{array}{c}\text { C3 } \\
2: 98\end{array}$ & $\begin{array}{c}\text { C4 } \\
5: 95\end{array}$ & $\begin{array}{c}\text { C5 } \\
10: 90\end{array}$ & $\begin{array}{c}C 6 \\
25: 75\end{array}$ & $\begin{array}{c}\text { C7 } \\
50: 50\end{array}$ & $\begin{array}{c}\text { C8 } \\
75: 25\end{array}$ & $\begin{array}{c}\text { C9 } \\
90: 10\end{array}$ & $\begin{array}{l}\text { C10 } \\
95: 5\end{array}$ & $\begin{array}{l}\text { C11 } \\
98: 2\end{array}$ & $\begin{array}{l}\mathrm{C} 12 \\
99: 1\end{array}$ & $\begin{array}{c}\text { C13 } \\
100: 0\end{array}$ \\
\hline $4 \pi \mathrm{Ms}$ (Gauss) & 2320 & 2300 & 2200 & 2190 & 2125 & 1940 & 1570 & 1720 & 1850 & 1850 & 1910 & 1830 & 1790 \\
\hline $\operatorname{Tc}\left({ }^{\circ} \mathrm{C}\right)$ & 330 & 330 & 335 & 337 & 335 & 355 & $>350$ & $>350$ & $>350$ & 278 & 280 & 278 & 280 \\
\hline$\Delta \mathrm{H}(\mathrm{Oe})$ & 300 & 320 & - & 300 & 400 & 640 & - & - & 470 & 60 & 50 & 50 & 50 \\
\hline$\rho_{\mathrm{dc}}(\Omega-\mathrm{cm})$ & $1 \times 10^{8}$ & $2 \times 10^{8}$ & $1 \times 10^{8}$ & $7 \times 10^{\prime}$ & $2 \times 10^{T}$ & $2 \times 10^{6}$ & $4 \times 10^{5}$ & $2 \times 10^{2}$ & $2 \times 10^{10}$ & $>10^{11}$ & $>10^{11}$ & $>10^{11}$ & $>10^{11}$ \\
\hline$\mu_{\mathrm{i}}$ (at $\left.1 \mathrm{kHz}\right)$ & 21 & 18 & 18 & 17 & 20 & 22 & 18 & 118 & 124 & 140 & 113 & - & 110 \\
\hline
\end{tabular}

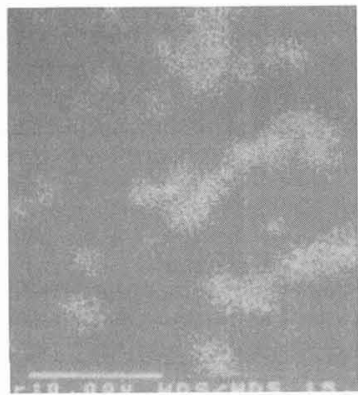

(a)

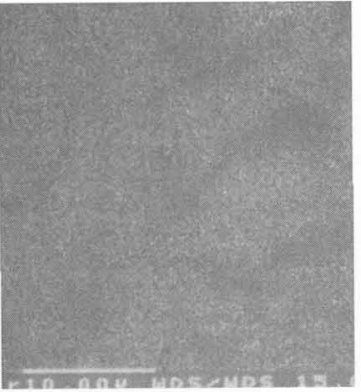

(b)
Fig. 1. Elemental scans for sample $C 6$. Regions appearing in white contrast depict $\mathrm{Y}$ in (a) and $\mathrm{Mg}$ in (b).
From table $I$ it is noted that the samples near the ends of the series largely follow the behaviour of parent members $\mathrm{C} 1$ and $\mathrm{C} 13$. Depending upon the relative concentrations the small content of the second phase is embedded in the major phase in the form of small grains. This is inferred from the microphotographs taken on samples using EPMA technique. The elemental maps of yttrium and magnesium is shown in Fig.1 for the sample $\mathrm{C6}$. The $\mathrm{Mg}$ and $\mathrm{Y}$ regions representing $\mathrm{MF}$ and $\mathrm{YIG}$, respectively, are complementary to each other. The grain size is estimated to be below $5 \mu \mathrm{m}$. In the micrographs $\mathrm{YFeO}_{3}$ is not distinguishable from the YIG as both appear as $\mathrm{Y}$ containing area.

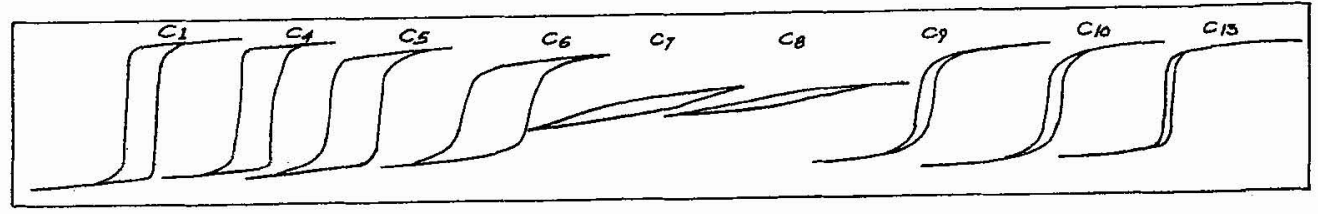

Fig. 2. BH loop tracings

The other properties show a notable departure from parent materials for samples with $>5$ wt $\%$ of the other phase. $4 \pi \mathrm{Ms}$ values become lower because of the contribution from $\mathrm{YFeO}_{3}$, which has a low $4 \pi \mathrm{Ms}$ value. Increase in $\Delta \mathrm{H}$ for intermediate samples is expected due to presence of the other phases. The $\rho_{\mathrm{dc}}$ of samples near the ends of the series are close to the values of the parents, but the $\mathrm{C} 7$ and $\mathrm{C} 8$ samples have quite low values. The formation of some $\mathrm{Fe}_{3} \mathrm{O}_{4}$ cannot be ruled out which could have led to this low resistivity values. The high Tc values observed for these samples could also be a consequence of this. The $\mu_{\mathrm{i}}$ value exibits an abrupt change after C7. The hysteresis loop behaviour varies a lot from a highly rectangular one for $\mathrm{MF}(\mathrm{R} \sim 0.9$ and $\mathrm{Hc} \sim 2.0 \mathrm{Oe}$ ) to a narrow loop for $\mathrm{YIG}(\mathrm{R} \sim 0.65$ and $\mathrm{Hc} \sim 0.5 \mathrm{Oe})$. Fig. 2 shows the tracings for some typical samples.

\section{REFERENCES}

[1] Boomgoard JVD, Terrel D R, Born RAJ and Giller HFJ, J. Mater. Sci., 9(1974)1705.

[2] Suryanarayana SV, Bull. Mater. Sci., 17(1994)1259.

[3] Piekarczyk W, Weppner W and Rabenau A, Mater. Res. Bull., 13(1978)1077.

[4] Thachenko EV, Shapovalov A G and Pozdnikov IP, J. Appl. Chem.(USSR), 52(1979)1088. 